\title{
Pengaruh Penggunaan Media Plastisin/Playdough Terhadap Kreativitas Anak Usia Dini di TK Mabdaul Falah Kelompok B Pesisir Kaduara Timur Sumenep
}

\author{
Evin Oktania Ariska ${ }^{1}$, Nina Khayatul Virdyna ${ }^{2}$ \\ Institut Agama Islam Negeri Madura ${ }^{1}$, Indonesia \\ evinoktaniaariska@gmail.com \\ Institut Agama Islam Negeri Madura², Indonesia
}

\begin{abstract}
This study aims to determine the effect of the uses of plasticine/playdough media on the creativity of young children in kindergarten Mabdaul Falah group B East Kaduara Coastal Sumenep and how much influence on children's creativity. This type of research is a quantitative research method of product moment correlation, because product moment correlation is method used to determine the level of relationship between two or more variables. Data collection techniques from this research are Questionnaire and Test. The location of this research was conducted in Mabdaul Kindergarten Falah Coastal East Kaduara Sumenep. The subjects of this study were group B with 17 children, consisting of 5 boys and 12 girls. The results showed that there was an influence of the use of plasticine/playdough media on children's creativity. This is indicated by obtaining a positive value of $r$ work value of 0.655 . Value of "r" work which is equal to 0.655 is greater than $r$ criticism of product moment both in $95 \%$ confidence interval and $99 \%$ confidence interval, where the $95 \%$ confidence interval is 0.482 and in the $99 \%$ confidence interval is 0.606 . So "r"work>"r"table and indicate that the work is significant, where there is an influence of the use of plasticine/playdough media on children's creativity. And it is also known that the value of "r"work which is worth 0.655 is between $0.40-0.70$. This means that variable $X$ (Use of Plasticine/Playdough Media) and variable $Y$ (Child Creativity) have sufficient relationships/correlations.
\end{abstract}

\section{Abstrak}

Penelitian ini bertujuan untuk mengetahui pengaruh

penggunaan media plastisin/playdough terhadap

Kata Kunci: Media; 
kreativitas anak usia dini di TK Mabdaul Falah kelompok B Pesisir Kaduara Timur Sumenep serta seberapa besar pengaruhnya bagi kreativitas anak. Jenis penelitian yang digunakan adalah Penelitian kuantitatif metode korelasi product moment, karena korelasi product moment adalah metode yang digunakan untuk mengetahui tingkat hubungan antara dua variable atau lebih. Teknik pengumpulan data dari penelitian in iadalah Angket (Kuesioner) dan Tes. Adapun lokasi penelitian ini dilaksanakan di TK Mabdaul Falah Pesisir Kaduara Timur Sumenep. Subjek penelitian ini adalah kelompok $B$ yang berjumlah 17 anak, yang terdiri dari 5 anak laki-laki dan 12 anak perempuan. Hasil penelitian menunjukkan bahwa terdapat pengaruh penggunaan media plastisin/playdough terhadap kreativitas anak. Hal ini ditunjukkan dengan diperolehnya nilai $r$ kerja nilai positif sebesar 0,655. Nilai $r$ kerja yang sebesar 0,655 adalah lebih besar dari kritik $r$ product moment baik dalam interval kepercayaan 95\% maupun interval kepercayaan $99 \%$, yang dimana interval kepercayaan 95\% adalah 0,482 dan dalam interval kepercayaan $99 \%$ adalah 0,606. Jadi $r_{\text {kerja }}>r_{\text {tabel }}$ dan menandakan bahwa $r$ kerja signifikan, dimana ada pengaruh penggunaan media plastisin/playdough terhadap kreativitas anak. Dan juga diketahui nilai $r$ kerja yang bernilai 0,655 berada diantara 0,40-0,70. Jadi, hipotesis kerja yang diajukan peneliti dapat diterima, dimana Ada pengaruh penggunaan media plastisin/playdough terhadap kreativitas anak usia dini di TK Mabdaul Falah Kelompok B Pesisir Kaduara Timur Sumenep dan dapat dipandang dengan interpretasi cukup berpengaruh.

Diterima : 20 November 2021; Direvisi: 22 Januari 2021; Diterbitkan: 27 Februari 2021 http://doi.org/10.19105/kiddo.v2i1.4216 cc) (i) (8)

(C) 2021 Evin Oktania Ariska, Nina Khayatul Virdyna

This is an open access article under the CC-BY-NC license

\section{Pendahuluan}

Anak usia dini adalah individu yang sedang mengalami proses pertumbuhan dan perkembangan yang sangat pesat, bahkan dikatakan sebagai lompatan perkembangan. Anak usia dini memiliki rentang usia yang sangat berharga dibanding usia-usia selanjutnya karena perkembangan kecerdasannya sangat luar biasa (Mulyasa, 2014 : 16). Jadi, pada masa ini merupakan masa yang unik, berbeda dengan masa lainnya dan dikatakan sebagai masa emas atau golden age dimana anak mampu secara cepat menyerap berbagai informasi yang diberikan kepadanya. Oleh sebab itu, dikatakan bahwa kecerdasan anak usia dini berkembang sangat luar biasa. Adapun 
salah satu karakteristik anak usia dini yaitu anak suka meniru dan bermain. Suka meniru maksudnya apa yang anak lihat dari seseorang dan sangat mengesankan bagi dirinya sehingga anak akan meniru dan melakukan sebagaimana yang ia lihat. Sedangkan anak suka bermain, maksudnya setiap anak usia dini merupakan usianya bermain. Artinya, anak akan mengisi hidup-hidup dalam kesehariannya dengan bermain.

Adapun dalam pasal 28 Undang-undang Sistem Pendidikan Nasional No.20 Tahun 2003 ayat 1, disebutkan bahwa yang termasuk anak usia dini adalah anak yang masuk dalam rentang usia 0-6 tahun (Fadlillah 2012:18) Pada masa anak usia dini ini, stimulasi seluruh aspek perkembangan memiliki peran penting untuk tugas perkembangan selanjutnya. Perkembangan anak usia dini merupakan periode yang sangat penting dan perlu mendapat penanganan sedini mungkin (Mulyasa 2014 : 20). Dan seperti yang sudah dikatakan, pertumbuhan dan perkembangan jasmani maupun rohani pada anak usia dini berkembang begitu sangat pesat. Oleh karena itu, kita harus memanfaatkan masa ini dengan sebaik mungkin, anak hanya di berikan pendidikan yang tepat, optimal dan seefektif mungkin supaya pertumbuhan dan perkembangannya dapat berkembang dengan baik.

PAUD sebagai pendidikan yang diselenggarakan sebelum jenjang pendidikan dasar, merupakan salah satu bentuk penyelenggaraan pendidikan yang menitikberatkan pada peletakan dasar ke arah pertumbuhan dan perkembangan fisik (koordinasi mororik halus dan kasar), kecerdasan (daya pikiran, daya cipta, kecerdasan emosi, kecerdasan spritual), sosial emosional (sikap dan perilaku serta beragama), bahasa dan komunikasi, sesuai dengan keunikan dan tahap-tahap perkembangan yang dilalui oleh anak usia dini (Mursid 2017:2). Dalam Undang-undang Nomor 20 Tahun 2003 tentang Sistem Pendidikan Nasional Pasal 1 angka 14 menyatakan bahwa Pendidikan anak usia dini (PAUD) adalah suatu upaya pembinaan yang ditujukan kepada anak sejak lahir sampai dengan usia enam tahun yang dilakukan melalui pemberian rangsangan pendidikan untuk membantu pertumbuhan dan perkembangan jasmani dan rohani agar anak memiliki kesiapan dalam memasuki pendidikan usia lanjut, baik pendidikan secara formal di sekolah maupun secara nonformal.

Adapun secara umum tujuan pendidikan anak usia dini adalah mengembangkan berbagai potensi anak sejak dini sebagai persiapan untuk hidup dan dapat menyesuaikan diri, dengan lingkungannya serta membentuk anak Indonesia yang berkualitas, dimana anak akan tumbuh dan berkembang sesuai tingkat perkembangannya sehingga memiliki kesiapan optimal dalam memasuki pendidikan dasar, serta mengarungi kehidupan di masa dewasanya (Mursid 2017 : 3). Anak memiliki berbagai tahapan yang harus dilalui, dan secara alamiah perkembangan anak berbeda-beda, salah satunya yaitu perkembangan kreativitas. Kreativitas merupakan kemampuan umum untuk menciptakan sesuatu yang baru, baik berupa produk atau gagasan baru yang dapat diterapkan dalam memecahkan masalah, atau sebagai kemampuan untuk melihat unsur-unsur yang sudah ada sebelumnya (Achmad susanto 2012 : 112). Jadi, dapat disimpulkan kreativitas adalah kemampuan seseorang untuk menghasilkan sesuatu 
yang baru, baik kemampuan untuk menghasilkan produk/karya nyata ataupun gagasan dari sesuatu yang sudah ada sebelumnya. Pengembangan kreativitas anak harus di berikan stimulasi dari mulai usia dini, sehingga anak akan terasa untuk berpikir kreatif, karena dengan kreativitaslah memungkinkan manusia menjadi berkualitas dan survive dalam hidupnya. Anak akan melihat masalah dari berbagai sudut pandang, mampu menghasilkan karya yang berbeda dari yang sudah ada sebelumnya (Susanto 2012 : 111).

Seperti yang sudah dikatakan, pengembangan kreativitas anak harus di berikan stimulasi dari mulai usia dini dan pendidikan anak usia dini merupakan saat yang paling tepat untuk mengembangkan kreativitas. Oleh karena itu, diperlukan adanya program-program permainan dan pembelajaran yang dapat memelihara dan mengembangkan potensi kreativitas anak. Hal ini juga didasarkan pada beberapa alasan yaitu: 1) Kreativitas merupakan manifestasi setiap individu. 2) Kreativitas merupakan kemampuan untuk mencari berbagai macam kemungkinan dalam menyelesaikan suatu masalah, sebagai bentuk pemikiran yang sampai sekarang belum mendapat perhatian dalam pendidikan anak usia dini. 3) Kegiatan kreatif tidak hanya bermanfaat bagi pengembangan pribadi dan lingkungannya, tetapi dapat memberikan kepuasan kepada anak. 4) Kreativitas memungkinkan setiap anak usia dini mengembangkan berbagai potensi dan kualitas pribadinya (Munandar 1999:31).

Kreativitas anak pun dapat di asah atau dilatih dengan guru menggunakan atau menerapkan media permainan. Karena melalui bermain anak dapat mempelajari banyak hal, tanpa disadari dan tanpa merasa terbebani (Mulyasa 2014: 98). Jadi, dengan bermain anak juga dapat belajar, oleh sebab itu bermain sambil belajar sangat tepat bagi sang anak. Bermain dapat membuat anak belajar dengan senang, dan dengan belajar melalui bermain anak dapat menguasai pelajaran yang lebih menantang. Adapun menurut Singer, mengemukakan bahwa bermain dapat digunakan anak-anak untuk menjelajahi dunianya, mengembangkan kompetensi dalam usaha mengatasi dunianya dan mengembangkan kreativitas anak (Suryana 2016:203).

Bermain merupakan suatu kegiatan yang menyenangkan dan spontan sehingga hal ini memberikan rasa aman secara psikologis pada anak. Rasa aman dan bebas secara psikologis merupakan kondisi yang penting bagi tumbuhnya kreativitas. Anak-anak diterima apa adanya, dihargai keunikannya, dan tidak terlalu cepat dievaluasi, akan merasa aman secara psikologis. Begitu pula anak yang diberikan kebebasan untuk mengekspresikan gagasannya. Keadaan bermain yang demikian berkaitan erat dengan upaya pengembangan kreativitas anak.

Kreativitas memberi anak kesenangan dan kepuasan pribadi yang sangat besar dan penghargaan yang memiliki pengaruh nyata pada perkembangan pribadinya. Bermain memberikan kesempatan pada anak untuk mengekspresikan dorongan-dorongan kreatifnya sebagai kesempatan untuk merasakan objek-objek dan tantangan untuk menemukan sesuatu dengan cara-cara baru, untuk menemukan penggunaan suatu hal secara berbeda, menemukan hubungan yang 
baru antara sesuatu dan sesuatu yang lain, Serta mengartikannya dalam banyak alternatif cara. Selain itu, bermain memberikan kesempatan pada individu untuk berpikir dan bertindak imajinatif, serta penuh daya khayal yang erat hubungannya dengan perkembangan kreativitas anak (Wiyana \& Barnawi 2014:202).

Jadi, dari pemaparan diatas dapat disimpulkan bahwa dalam mengembangkan kreativitas dalam diri anak dapat dilakukan dengan cara menerapkan permainan. Permainan merupakan media pembelajaran yang dapat meningkatkan kreativitas dan segala potensi yang dimiliki anak juga sangat disukai si anak karena mengurangi rasa jenuh pada saat anak belajar.

Serta media pembelajaran mempunyai peran yang sangat penting dalam mengembangkan kreativitas anak usia dini, terutama media permainan tersebut. Oleh sebab itu seorang guru harus lebih kreatif lagi dalam menyiapkan media pembelajaran bagi anak. Karena terkadang seorang guru hanya selalu menyiapkan media pembelajaran berbentuk lembar kerja siswa, sehingga membuat anak cepet bosan dan proses pembelajaran akan terlihat menoton. Maka dari itu, perlu disiapkan dengan baik media yang dapat memfasilitasi perkembangan kreativitas anak.

Adapun di TK Mabdaul Falah yang berlokasi di desa Kaduara Timur kecamatan Pragaan kabupaten Sumenep, dan merupakan sebuah lembaga pendidikan yang berada dibawah naungan Yayasan Mabdaul Falah, yang mana dalam proses pembelajarannya menggunakan Kurikulum 2013 dan salah satu prinsip pengembangan kurikulum tersebut yaitu berorientasi sambil belajar atau belajar seraya bermain serta kreatif dan inovatif. Dan adapun itu, dalam proses pembelajarannya pada kelompok B cukup sering menggunakan media plastisin/playdough. Plastisin/playdough merupakan salah satu media bermain edukatif. Plastisin/playdough bertekstur lunak, sehingga mudah dibentuk menyerupai bentuk benda yang diinginkan. Anak suka dengan plastisin karena dengan plastisin anak dapat meremas-remas, menekan, membentuk plastisin/playdough menjadi bentuk benda, binatang, orang dan sebagainya, sesuai kreasi dan imajinasi anak. Plastisin/playdough merupakan bahan yang digunakan untuk bermain oleh anak-anak di kelas. Plastisin/playdough memberikan pengalaman yang menyenangkan dan memuaskan bagi anak, namun bukan hanya aktivitas bersenang-senang. Melalui media ini, guru dapat menggunakan sebagai salah satu cara untuk mengobservasi perkembangan anak dalam berbagai area perkembangan (Sari 2013:220)

Serta dalam menggunakan media plastisin/playdough ini, guru di TK Mabdaul Falah mengajak anak bermain dengan bereksplorasi menggunakan media tersebut dan membuat anak secara aktif menggunakan imajinasinya. Karena guru disana memberikan kesempatan atau keluasan kepada anak untuk membentuk plastisin/playdough sesuai dengan imajinasinya sendiri. Misalnya pada sub tema buah-buahan, disini anak diminta bermain plastisin dengan berkreasi membentuk buah berdasarkan imajinasi anak. 
Oleh sebab itu pun peneliti tertarik untuk melakukan penelitian dengan judul "Pengaruh Penggunaan Media Plastisin/Playdough Terhadap Kreativitas Anak Usia Dini Di TK Mabdaul Falah Kelompok B Pesisir Kaduara Timur Sumenep.

\section{Metode}

Adapun dalam penelitian ini menggunakan metode kuantitatif. Metode kuantitatif merupakan suatu proses menemukan pengetahuan yang menggunakan data berupa angka sebagai alat menemukan keterangan mengenai apa yang ingin kita ketahui (Margono, 2010:105). Sedangkan jenis penelitian ini adalah korelasi. Yaitu penelitian yang dilakukan oleh peneliti untuk mengetahui tingkat hubungan antara dua variabel atau lebih, tanpa melakukan perubahan, tambahan atau manipulasi terhadap data yang memang sudah ada (Suharsimi, 2014:4).

Adapun populasi pada penelitian ini adalah seluruh peserta didik di kelompok B TK Mabdaul Falah Pesisir Kaduara Timur Sumenep yang berjumlah 17 anak, dimana terdiri dari 5 anak laki-laki dan 12 anak perempuan. Dalam penelitian dipilih kelompok $B$ karena menurut piaget usia 5-6 tahun merupakan masa pra operasional kongkret dimana pada masa ini anak dapat memanipulasi objek simbol, jadi dalam menggunakan media plastisin/playdough kelompok B dimana usia rata-rata 5-6 tahun dalam menggunakan media plastisin/playdough lebih baik. Dan sampel dalam penelitian ini penulis mengambil sampel sebanyak populasi yaitu 17 anak.Karena menurut Suharsimi Arikunto, apabila subyeknya kurang dari 100, lebih baik diambil semuanya, sehingga penelitiannya merupakan penelitian populasi. Selanjutnya, apabila jumlah subyeknya besar dapat di ambil antara $10-15 \%$ atau 20-25\% atau lebih (Dimyati, 2014 : 58).

Lokasi penelitian dilakukan di TK Mabdaul Falah, dusun Pragaan, desa Kaduara Timur, kecamatan Pragaan, kabupaten Sumenep. Serta dilaksanakan pada Awal semester II tahun ajaran 2019/2020 yaitu pada tanggal 09-11 Januari 2020.Adapun Instrumen yang digunakan dalam penelitian ini yaitu angket/kuesioner, tes dan dokumentasi.

Dalam penelitian ini peneliti menggunakan analisis kuantitatif (suatu proses menemukan pengetahuan yang menggunakan data berupa angka) hasil dari data penelitian dari kelompok B TK Mabdaul Falah Pesisir Kaduara Timur Sumenep. Untuk menganalisis tersebut, digunakan teknik analisa korelasi product moment, karena korelasi product moment digunakan misalnya untuk menentukan hubungan antara dua gejala interval.

\section{Hasil dan Pembahasan}

Setelah peneliti melakukan penelitian pada peserta didik di kelompok B TK mabdaul falah pesisir kaduara timur menggunakan istrument angket dan tes, peneliti mendapatkan hasil temuan bahwa Penggunaan media plastisin/playdough berpengaruh terhadap kreativitas anak di kelompok B TK Mabdaul Falah pesisir kaduara timur. Ini semua dibuktikan setelah adanya di adakan penelitian dan analisis dari data skala penilaian (tes dan angket), dimana diketahui 
bahwa nilai " $r$ " kerja memiliki nilai positif sebesar 0,655. Nilai" $r$ " kerja yang sebesar 0,655 adalah lebih besar dari kritik $r$ product moment baik dalam interval kepercayaan $95 \%$ maupun interval kepercayaan $99 \%$, yang dimana interval kepercayaan 95\% adalah 0,482 dan dalam interval kepercayaan 99\% adalah 0,606. Jadi $r_{\text {kerja }}>r_{\text {tabel }}$ dan menandakan bahwa $r$ kerja signifikan, dimana ada pengaruh penggunaan media plastisin/playdough terhadap kreativitas anak.

Hasil ini pun sesuai dengan pembahasan yang telah dipaparkan pada bab 2, dimana pendapat Ismail dalam jurnal Kartini, yang mengatakan bahwa media plastisin dapat melatih sekaligus mengembangkan kreativitas anak. Sebab, dengannya anak dapat melakukan aktivitas eksplorasi dalam membuat bentuk model secara bebas dan spontan. Dalam bermain plastisin anak juga dapat menemukan ide-ide baru ketika bermain plastisin/playdough ini, sehingga melatih anak untuk kreatif. Pada saat peneliti melakukan penelitian dan menginstruksikan anak untuk membuat bentuk bunga dari plastisin/playdough, anak antusias berkesplorasi untuk membuat bentuk bunga yang indah sehingga mereka menghasilkan ide-ide kreatif yang membuat hasil karyanya unik dan menarik. Anak pun dapat membangun dan menggali semua pengetahuan melalui pengalamannya sendiri dan ini semua dapat melatih dan mengembangkan kreativitas dalam diri anak tersebut. Selain itu, dengan penggunaan media plastisin ini, keterampilan motorik halus anak berkembang dengan baik, terbukti dengan lihai nya anak-anak membuat bentuk plastisin dengan baik.

Penting bagi guru untuk menggunakan media dalam proses belajar mengajar, terutama media platisin/playdough supaya anak menjadi produktif dan kreatif. Plastisin/playdough ini bertekstur lunak, sehingga mudah dibentuk menyerupai bentuk benda yang diinginkan. Anak suka dengan plastisin karena dengan plastisin anak dapat meremas-remas, menekan, membentuk plastisin/playdough menjadi bentuk benda, binatang, orang dan sebagainya, sesuai kreasi dan imajinasi anak. Oleh sebab itu dengan bermain menggunakan media plastisin/playdough ini mampu mengasah dan mengembangkan kreativitas anak. Serta kreativitas sangat penting untuk dikembangkan sejak usia dini dikarenakan kreativitas sangat berpengaruh sekali dalam pengembangan aspek-aspek perkembangan anak usia dini, apabila kreativitas anak tidak dikembangkan sejak dini maka kemampuan kecerdasan dan kelancaran dalam berfikir anak tidak berkembang karena untuk menciptakan suatu produk dan bakat kreativitas yang tinggi diperlukan kecerdasan yang cukup tinggi pula.

Adapun pada saat ini masih cukup banyak lembaga pendidikan anak usia dini yang lebih menekankan pengetahuan dalam hal menulis dan membaca, padahal tidak dapat dipungkiri perkembangan kreativitas juga sangat penting untuk di asah sejak dini, oleh sebab itu peneliti berusaha memberikan konstribusi dalam dunia pendidikan anak usia dini supaya kreativitas anak terasah dengan baik dengan menggunakan media pembelajaran plastisin/playdough.

Adapun hasil temuan penelitian selanjutnya yaitu Penggunaan media plastisin/playdough berpengaruh cukup signifikan terhadap 
kreativitas anak di kelompok B TK Mabdaul Falah Pesisir Kaduara Timur Sumenep. Ini dibuktikan dengan peneliti mengkonsultasikan nilai $r$ kerja dengan tabel interpretasi nilai $r$ product moment dan diketahui nilai $r$ kerja yang bernilai 0,655 berada diantara 0,40-0,70. Ini artinya variabel $X$ dan variabel $Y$ memiliki hubungan/korelasi yang cukup. Jadi, Penggunaan media plastisin/playdough memang cukup sangat mendukung terhadap pembentukan kreativitas anak. Dengan berrmain plastisin, anak-anak dapat mengekspresikan kreativitas mereka dengan menemukan serta membuat gaya-gaya unik dari cara berekspresi masing-masing. Manfaat bermain menggunakan media plastisin ini pun yaitu anak dapat mengkoordinasikan jari-jari tangan, melenturkan otot-otot jari tangan, melatih keuletan dan kesabaran serta mengembangkan imajinasi dan kreativitas anak. Penggunaan plastisin atau playdough juga memberikan pengalaman menyenangkan bagi anak dan mengasah kemampuan berpikir anak, dimana bagi anak usia dini bermain playdough dapat membantunya membuat karya tiga dimensi melalui imajinasi dan kreativitas serta kemampuannya dalam berpikir. Ketika anak-anak menggunakan plastisin atau playdough mereka mengeksplorasi ide-ide dan terus mencoba, membuat bentuk sesuai imajinasi mereka, memuaskan rasa ingin tahu, dan memberikan pengalaman yang membantu anak mengenal dunia sekitarnya.

\section{Kesimpulan}

Setelah peneliti melakukan penelitian tentang pengaruh penggunaan media plastisin/playdough pada peserta didik di kelompok B TK mabdaul falah pesisir kaduara timur menggunakan istrument angket dan tes, peneliti mendapatkan hasil temuan bahwa Penggunaan media plastisin/playdough berpengaruh terhadap kreativitas anak di kelompok B TK Mabdaul Falah pesisir kaduara timur dan juga Penggunaan media plastisin/playdough ini berpengaruh cukup signifikan terhadap kreativitas anak di kelompok B TK Mabdaul Falah Pesisir Kaduara Timur Sumenep. Sebab, dengan bermain plastisin/playdough anak dapat melakukan aktivitas eksplorasi dalam membentuk plastisin dan disini anak juga dapat menemukan ide-ide baru ketika bermain plastisin/playdough, sehingga melatih anak untuk kreatif.

Adapun pada saat ini masih cukup banyak lembaga pendidikan anak usia dini yang lebih menekankan pengetahuan dalam hal menulis dan membaca, padahal tidak dapat dipungkiri perkembangan kreativitas juga sangat penting untuk di asah sejak dini, oleh sebab itu peneliti berusaha memberikan konstribusi dalam dunia pendidikan anak usia dini supaya kreativitas anak terasah dengan baik, salah satunya dengan cara menggunakan media pembelajaran plastisin/playdough.

\section{Ucapan Terima Kasih}

Penulis menyadari atas segala kekurangan, kelemahan dan keterbatasan ilmu yang dimiliki. Oleh karena itu, tulisan ini tidak akan selesai tanpa adanya bantuan dari beberapa pihak. Dari setiap bantuan tersebut Peneliti mengucapkan terimakasih yang tiada tara kepada 
Orang tua, Dosen Pembimbing dan kepada guru-guru di TK Mabdaul Falah Pesisir Kaduara Timur Sumenep.

\section{Daftar Pustaka}

Sumardi. (2017). "Peningkatan Kemampuan Anak Usia Dini Mengenal Lambang Bilangan Melalui Media Playdough. "Jurnal PAUD Agapedia, Vol.1 No. 2, Desember.

Sari, Dynna Wahyu Perwita. (2013)."Pengaruh Bermain Plastisin Terhadap Kreativitas Anak Usia 5-6 Tahun Ditinjau dari Bermain Secara Individu dan Kelompok. "Jurnal Psikologi dan perkembangan, vol 02. No. 03 Desember.

Arikunto, Suharsimi. (2014). Prosedur Penelitian Suatu Pendekatan Praktek. Jakarta: Rineka Cipta.

Fadlillah, Muhammad. (2014). Edutaiment Pendidikan Anak Usia Dini. Jakarta: Prenadamedia Group.

Dimyati, Johni. (2014). Metodologi Penelitian Pendidikan dan Aplikasinya pada Pendidikan Anak Usia Dini. Jakarta: Kencana Prenadamedia Group.

Latif, Mukhtar, dkk. (2016). Orientasi Pendidikan Anak Usia Dini. Jakarta: Prenadamedia Group.

Margono. (2010). Metodologi Penelitian Pendidikan. Jakarta: Rineke Cipta.

Mulyasa. (2014). Manajemen PAUD, Bandung: PT Remaja Rosdakarya.

Mursid. (2015). Belajar dan Pembelajaran PAUD. Bandung: PT Remaja Rosdakarya.

Munandar, Utami. (1999). Pengembangan Kreativitas Anak Berbakat. Jakarta: PT Rineka Cipta.

Soewadji, Jusuf. (2012). Pengantar Metodologi Penelitian. Jakarta: Mitra Wacana Media.

Sudjana, Nana dan Ibrahim. (2012). Penelitian dan Penilaian. Bandung:Sinar Baru Algensindo.

Susanto, Achmad. (2012). Perkembangan Anak Usia Dini. Jakarta: Kencana Prenada Media Group.

Wiyana, Novan Ardy dan Barnawi. (2014). Format Paud. Jogjakarta: ArRuzz Media. 